\title{
PENGARUH RETURN ON ASSETS, DEBT TO EQUITY RATIO, DAN EARNING PER SHARE TERHADAP NILAI PERUSAHAAN \\ (Studi Kasus Pada Perusahaan Food and Beverages Yang Terdaftar Di BEI Periode 2009-2011)
}

\author{
Winur Haryati* \\ Sri Ayem \\ Program Studi Akuntansi Fakultas Ekonomi \\ Universitas Sarjanawiyata Tamansiswa Yogyakarta \\ *lyaaltesa@gmail.com
}

\begin{abstract}
This study aims to determine whether the return on assets, debt to equity ratio, and earnings per share have an influence on the value of the company at the company's food and beverages. The research data collection using polling, so the amount of data to be processed is the product of the number of samples with the company during the period of observation period, which is 14 times the company 3 years, so that the resulting sample of 42. Data analysis was performed using linear regression analysis using SPSS for windows 16. Simultaneous testing results show that the return on assets $\left(X_{1}\right)$, debt to equity ratio $\left(X_{2}\right.$ ), and earnings per share $\left(X_{3}\right)$ all positive and significant effect on firm value, while the partial test results show that of the three independent variables, namely, return on assets, debt to equity ratio, earnings per share and there are two variables are positive and significant effect on firm value is variable return on assets and earnings per share, while the debt to equity ratio variable had no significant effect on firm value.
\end{abstract}

Keywords: Return on assets, debt to equity ratio, earnings per share

\section{PENDAHULUAN \\ Latar Belakang}

Persaingan perusahaan barang konsumsi makanan dan minuman semakin lama menjadi semakin ketat sejak disahkannya organisasi perdagangan dunia. Dengan terbentuknya World Trade Organization (WTO) di tahun 1994 pasar dunia cenderung semakin terbuka dan bebas hambatan (Riyadi, 2012 dalam Pertiwi dan Pratama, 2012). Untuk itu perusahaan industri barang konsumsi makanan dan minuman di Indonesia memerlukan dana tambahan untuk menjaga kelangsungan hidup perusahaan, serta mampu bersaing dengan produk luar negeri.

Penelitian ini menggunakan perusahaan food and beverages sebagai penelitian karena saham yang berasal dari produk makanan dan minuman merupakan saham yang banyak diminati oleh investor.
Saham pada perusahaan food and beverages tidak terpengaruh oleh pergerakan situasi ekonomi makro atau kondisi bisnis secara umum, perusahaan tersebut mampu memberikan bagian keuntungan yang diberikan

Salah satu pengelolaan yang harus diperhatikan perusahaan adalah masalah keuangan yang penting bagi kelangsungan hidup perusahaan, keuangan suatu perusahaan berkaitan dengan sumber dana dan penggunaannya. Semakin efisien penggunaan dan pengelolaan dana berarti semakin baik bagi perusahaan. Agar dana dalam perusahaan dapat dipenuhi secara cukup, maka diperlukan pengelolaan dan penentuan sumber dana secara tepat. Untuk itu, perusahaan harus memperkuat faktor internal agar dapat tetap berkembang dan bertahan. Salah satu faktor internalnya adalah perusahaan dapat melakukan 
pembenahan dalam manajemen untuk meningkatkan efektivitas dan efisiensi kerja atau melaksanakan ekspansi usaha dalam rangka mengoptimalkan pangsa pasar yang berpotensial serta memperoleh nilai perusahaan yang tinggi.

Nilai perusahaan diartikan sebagai harga yang bersedia dibayar oleh calon investor seandainya suatu perusahaan akan dijual. Nilai perusahaan tercermin dari harga saham yang stabil dan dalam jangka panjang mengalami kenaikan. Semakin tinggi harga saham maka semakin tinggi pula nilai perusahaan. Menurut Baridwan (2004:443) dalam Priatinah dan Kusuma (2012) yang dimaksud dengan Earning Per Share (EPS) atau laba per saham adalah jumlah pendapatan yang diperoleh dalam satu periode untuk setiap lembar saham yang beredar.

Return On Assets adalah rasio yang digunakan untuk menilai seberapa besar tingkat pengembalian dari aset yang dimiliki perusahaan. Debt to Equity Ratio menunjukkan perbandingan antara hutang dengan ekuitas. Bila perusahaan dapat mengatur kombinasi yang optimal antara pinjaman utang dan modal sendiri, maka perusahaan dapat memaksimalkan nilai perusahaan.

Penelitian ini mengacu pada penelitian yang dilakukan Pertiwi dan Pratama (2012) menunjukkan bahwa ROA berpengaruh positif terhadap nilai perusahaan, penelitian yang dilakukan Meythi (2012) menunjukkan bahwa struktur modal berpengaruh negatif terhadap nilai perusahaan, dan penelitian Yulistiana (2010) yang menunjukkan bahwa Earning Per Share (EPS) berpengaruh negatif terhadap nilai perusahaan.

\section{METODE PENELITIAN}

Variabel penelitian adalah suatu atribut atau sifat (nilai dari orang, objek atau kegiatan) yang mempunyai variasi tertentu yang ditetapkan oleh peneliti untuk dipelajari dan ditarik kesimpulannya (Sugiyono, 2007). Dalam penelitian ini digunakan dua (2) variabel, yaitu sebagai berikut:
1. Variabel Dependen (Variabel Terikat) Variabel dependen adalah variabel yang diterangkan atau mendapat pengaruh dari variabel lainnya (Sugiyono, 2007). Dalam Penelitian ini, peneliti menggunakan variabel dependen berupa Nilai Perusahaan menggunakan alat ukur Tobins $Q$.

2. Variabel Independen (Variabel Bebas)

Variabel Independen adalah variabel yang berfungsi menerangkan atau mempengaruhi variabel lainnya (Sugiyono, 2007). Dalam penelitian ini ada 3 (empat) variabel independen yang digunakan, yaitu Return On Assets, Debt to Equity Ratio, dan Earning Per Share.

\section{Definisi Operasional}

\section{Return On Asset (ROA)}

Menurut Brigham (2006:109) dalam Yuniasih dan Wirakusuma (2008) Return On Asset (ROA) dapat dirumuskan sebagai berikut :

ROA $=\frac{\text { Net Income After Tax }}{\text { Total Asset }} \times 100 \%$

Keterangan :

Net Income After Tax : Pendapatan bersih sesudah pajak

Total Asset : : Total Aktiva

\section{Debt to Equity Ratio (DER)}

Menurut Dendawijaya (2005:121) dalam Barasa (2009) Debt to Equity Ratio adalah rasio yang digunakan untuk mengukur kemampuan perusahaan dalam menutup sebagian/seluruh hutang-hutangnya baik jangka panjang maupun jangka pendek dengan dana yang berasal dari modal sendiri. DER dapat dihitung dengan rumus :

Hutang Lancar + Hutang Jangka Panjang

DER =

Jumlah Modal Sendiri 


\section{Earning Per Share}

Earning Per Share atau laba per lembar saham adalah tingkat keuntungan bersih untuk tiap lembar saham yang mampu diraih perusahaan pada saat menjalankan operasinya.

Untuk menentukan EPS digunakan rumus :

\section{Nilai Perusahaan}

Menurut Smithers dan Wright (2007:37) dalam Prasetyorini (2013) menyebutkan bahwa nilai perusahaan dihitung melalui Tobins $Q$, yang diformulasikan (dengan satuan persentase) :

EPS $=\frac{\text { Laba Bersih }}{\text { Jumlah Saham Beredar }}$

$$
=\frac{\{(\mathrm{CP} \times \text { jumlah saham yang beredar })+\mathrm{TL}+\mathrm{I})\}-\mathrm{CA}}{\mathrm{TA}}
$$

Di mana :

$$
\begin{aligned}
& \text { Tobins } Q=\text { Nilai perusahaan } \\
& \mathrm{CP} \quad=\text { Closing Price } \\
& \mathrm{TL} \quad=\text { Total Liabilities } \\
& \text { I } \quad=\text { Inventory } \\
& \text { CA = Current Assets }
\end{aligned}
$$

$\mathrm{TA}=$ Total Assets

\section{Populasi}

Populasi adalah sekelompok orang, kejadian atau segala sesuatu yang mempunyai karakteristik tertentu (Sugiyono, 2007). Populasi dalam penelitian ini adalah semua perusahaan food and beverages yang terdaftar di Bursa Efek Indonesia (BEI) periode 20092011 yaitu 17 perusahaan.

\section{Sampel}

Sampel adalah sebagian dari populasi yang memiliki karakteristik sama dan dianggap bisa mewakili populasi (Sugiyono, 2007). Sampel dalam penelitian ini diambil dengan metode purposive sampling, artinya sampel dipilih dengan kriteria tertentu.

Sampel yang dipilih dalam penelitian ini adalah perusahaan Food and Beverages di BEI dengan kriteria sebagai berikut:
1. Semua perusahaan food and beverages yang terdaftar di BEI pada periode 20092011.

2. Semua perusahaan food and beverages yang mempublikasikan laporan keuangan yang telah di audit pada periode 20092011.

3. Semua perusahaan food and beverages yang menyajikan laporan keuangan secara lengkap sesuai dengan variabel yang akan diteliti.

Berdasarkan kriteria tersebut, maka diperoleh sampel sebanyak 14 perusahaan food and beverages selama periode 2009-2011, sehingga jumlah sampel yang akan diteliti selama 3 tahun sebanyak 42 . 
Tabel 1

Sampel Perusahaan Food and Beverages

Yang Terdaftar di Bursa Efek Indonesia

Periode 2009-2011

\begin{tabular}{cll}
\hline NO. & CODE & \multicolumn{1}{c}{ NAMA PERUSAHAAN } \\
\hline 1 & AISA & Tiga Pilar Sejahtera Food Tbk. \\
2 & CEKA & Cahaya Kalbar Tbk. \\
3 & DLTA & Delta Djakarta Tbk \\
4 & FAST & Fast Food Indonesia Tbk. \\
5 & INDF & Indofood Sukses Makmur Tbk. \\
6 & MYOR & Mayora Indah Tbk. \\
7 & PSDN & Prasidha Aneka Niaga Tbk. \\
8 & PTSP & Pioneerindo Gourmet International Tbk. \\
9 & SIPD & Sierad Produce Tbk. \\
10 & SKLT & Sekar Laut Tbk. \\
11 & SMAR & Sinar Mas Agro Resources And Technology Tbk. \\
12 & STTP & Siantar Top Tbk. \\
13 & TBLA & Tunas Baru Lampung Tbk. \\
14 & ULTJ & Ultrajaya Milk Industry \& Trading Company Tbk. \\
\hline
\end{tabular}

Sumber : www.idx.co.id, diolah.

\section{Populasi dan Sampel}

Tabel 2

Populasi dan Sampel

\begin{tabular}{llll}
\hline No & Karakteristik Sampel & $\begin{array}{l}\text { Jumlah } \\
\text { Perusahaan }\end{array}$ & $\begin{array}{c}\text { Jumlah } \\
\text { Sampel }\end{array}$ \\
\hline
\end{tabular}

1. Semua perusahaan food and beverages yang terdaftar di BEI pada periode 2009-2011.

$$
17 \times 3
$$

$17 \times 3$

mempublikasikan laporan keuangan yang telah di audit pada periode 2009-2011.

3. Semua perusahaan food and beverages yang menyajikan laporan keuangan secara lengkap sesuai dengan variabel yang akan diteliti.

Populasi yang terpilih menjadi sampel

\begin{tabular}{ll}
$14 \times 3$ & 42 \\
$\mathbf{1 4} \times \mathbf{3}$ & $\mathbf{4 2}$ \\
\hline
\end{tabular}

Jumlah perusahaan yang sesuai dengan karakteristik sampel ada 14 perusahaan sehingga selama periode tahun 2009-2011 sampel yang dapat digunakan dalam penelitian ini adalah 42, yang didapat dari perhitungan jumlah perusahaan dikalikan periode tahun yang akan diteliti, yakni 14 perusahaan dikalikan 3 tahun, sehingga dihasilkan sampel sebanyak 42. 


\section{Teknik Analisis Data}

1. Uji Penyimpangan Asumsi Klasik

a. Uji Normalitas

Untuk mendeteksi normalitas data dapat diuji dengan Kolmogorof-Smirnof, dengan pedoman pengambilan keputusan:

1) Nilai sig atau signifikansi atau nilai probabilitas $<0,05$, distribusi adalah tidak normal.

2) Nilai sig atau signifikansi atau nilai probabilitas > 0,05, distribusi adalah normal (Ghozali, 2006 dalam Puspita, 2011).

\section{b. Uji Multikolonieritas}

Uji ini bertujuan untuk menguji apakah dalam model regresi ditemukan adanya korelasi antar variabel bebas atau tidak. Model yang baik seharusnya tidak terjadi korelasi yang tinggi diantara variabel bebas (Gozali, 2006 dalam Puspita, 2011). Untuk mendeteksi ada atau tidaknya multikolonieritas didalam model regresi dapat diketahui dari nilai toleransi dan nilai variance inflation factor (VIF). Tolerance mengukur variabilitas variabel bebas yang terpilih yang tidak dapat dijelaskan oleh variabel bebas lainnya. Jadi nilai tolerance rendah sama dengan nilai VIF tinggi (karena $\mathrm{VIF}=1 /$ tolerance) dan menunjukkan adanya kolonieritas yang tinggi. Nilai cut off yang umum dipakai adalah nilai tolerance 0,10 atau sama dengan nilai VIF di atas 10 .

\section{c. Uji Heteroskedastisitas \\ Uji mendeteksi ada tidaknya} heteroskedastisitas dapat dilakukan dengan berbagai cara salah satunya adalah dengan grafik plot antara nilai prediksi variabel terikat (variabel dependen) yaitu ZPRED dengan residualnya SRESID, dimana sumbu $\mathrm{Y}$ adalah $\mathrm{Y}$ yang telah di prediksi dan sumbu $\mathrm{X}$ adalah residualnya ( $\mathrm{Y}$ prediksi- $\mathrm{Y}$ sesungguhnya). Jika ada pola tertentu yang teratur (bergelombang, melebar, kemudian menyempit), maka mengindikasikan telah terjadi heteroskedastisitas. Jika tidak ada pola yang jelas, serta titik-titik menyebar di atas dan di bawah angka 0 pada sumbu Y, maka tidak terjadi heteroskedastisitas.

\section{d. Uji Autokorelasi}

Pengambilan keputusan ada tidaknya autokorelasi (Ghozali, 2006 dalam Puspita, 2011) :

1) Bahwa nilai DW terletak diantara batas atas atau upper bound (du) dan (4-du), maka koefisien autokorelasi sama dengan nol berarti tidak ada autokorelasi positif.

2) Bila nilai DW lebih rendah daripada batas bawah atau lower bound (dl),maka koefisien autokorelasi lebih besar dari nol berarti ada autukorelasi positif.

3) Bila nilai DW lebih besar daripada batas bawah atau lower bound (4-dl), maka koefisien autokorelasi lebih kecil dari nol berarti ada autokorelasi negatif.

4) Bila nilai DW terletak antara batas atas (du) dan batas bawah (dl) atau DW terlatak antara (4-du) dan (4-dl), maka hasilnya tidak dapat disimpulkan.

\section{Analisis Regresi dan Pengujian Hipotesis}

\section{Analisis Regresi Linear Berganda}

Untuk mengetahui pengaruh secara simultan digunakan uji $\mathrm{F}$ dan pengaruh secara parsial digunakan uji t. Persamaan model regresi linear berganda adalah :

$$
\mathbf{Y}=\alpha+\boldsymbol{\beta}_{1} \mathbf{X}_{1} \quad{ }_{2} \mathbf{X}_{2} \quad{ }_{3} \mathbf{X}_{3}+\mathrm{e}
$$

Keterangan :

\begin{tabular}{|c|c|}
\hline & $=$ Nilai Perusahaan \\
\hline & $=$ Konstanta \\
\hline $1, \beta 2, \beta 3$ & $=$ Koefisisen Determinasi \\
\hline$X_{1}$ & $=$ Return On Asset (ROA) \\
\hline & $=$ Debt to Equity Ratio (DE \\
\hline & $=$ Equity Per Share (EPS) \\
\hline & $=$ Variabel Pengganggu \\
\hline
\end{tabular}

\section{Pengujian Hipotesis \\ a. Uji F}

Analisis F-test dengan langkah-langkah sebagai berikut :

1) Merumuskan hipotesis statistik 
$\mathrm{HO}: \beta \mathrm{i}=0$ berarti tidak ada pengaruh variabel bebas secara serempak (simultan) terhadap variabel terikat.

Hi : minimal satu dari $\beta i \neq 0$ artinya variabel bebas berpengaruh signifikan terhadap variabel terikat.

2) Menentukan tingkat keyakinan $=95 \%$ dengan $\alpha=5 \%$, dan degree of freedom $(\mathrm{df})=$ pembilang $(\mathrm{k}-\mathrm{l})$, df penyebut ( $\mathrm{n}-$ k) untuk mengetahui nilai $F_{\text {tabel }}$ (uji satu sisi).

3) Menentukan besarnya $F_{\text {hitung }}$ yang diperoleh dari hasil pengujian dengan program SPSS 16.0.

4) Membandingkan $F_{\text {hitung }}$ dengan $F_{\text {tabel }}$ Terima $\mathrm{HO}$ : bila $\mathrm{F}_{\text {hitung }} \leq \mathrm{F}_{\text {tabel }}$

Tolak HO : bila $\mathrm{F}_{\text {hitung }}>\mathrm{F}_{\text {tabel }}$ atau Apabila tingkat signifikansi $\mathrm{F}<\alpha=$ 0,05 maka HO ditolak

Apabila tingkat signifikansi $\mathrm{F} \geq \alpha=$ 0,05 maka HO diterima

\section{b. Uji t}

Analisis t-test dengan langkah-langkah sebagai berikut:

1) Merumuskan hipotesis statistik $\mathrm{HO}: \beta \mathrm{i}=0$, artinya secara parsial $\mathrm{Xi}$ tidak berpengaruh terhadap $\mathrm{Y}$.

$\mathrm{H} 1: \beta \mathrm{i} \neq 0$, artinya secara parsial $\mathrm{Xi}$ berpengaruh terhadap Y.

2) Menentukan tingkat keyakinan $95 \%$ dengan $\alpha=5 \%$, dan $d f=(n-k)$ untuk mengetahui $t_{\text {tabel }}$.
3) Menentukan besarnya $t_{\text {hitung }}$ yang diperoleh dari hasil pengujian dengan program SPSS 16.0.

4) Membandingkan $t_{\text {hitung }}$ dengan $t_{\text {tabel }}$

Terima $\mathrm{HO}$ : bila $t_{\text {hitung }} t_{\text {tabel }}$

Tolak HO : bila $t_{\text {hitung }} \geq t_{\text {tabel }}$

Apabila tingkat signifikansi $\mathrm{t}<a=$ 0,05 maka HO ditolak

Apabila tingkat signifikansi $\mathrm{t} \geq \alpha=$ 0,05 maka HO diterima

\section{c. $\quad \mathrm{Uji}^{2}$}

Untuk mengetahui adanya hubungan yang tinggi, sedang atau rendah antara kedua variabel berdasarkan nilai $r$ (koefisien korelasi) digunakan penafsiran atau interpretasi angka sebagai berikut :

\section{Tabel 3}

Sumber : Sugiyono, 2007

\begin{tabular}{ll}
\hline Interval Koefisien & Tingkat Hubungan \\
\hline $0.00-0.199$ & Sangat Rendah \\
$0.20-0.399$ & Rendah \\
$0.40 \quad 0.599$ & Sedang \\
$0.60-0.799$ & Tinggi \\
$0.80-1.000$ & Sangat Tinggi \\
\hline
\end{tabular}

\section{HASIL DAN PEMBAHASAN \\ Statistik Deskriptif Variabel Penelitian}

Tabel 4

Descriptive Statistics

\begin{tabular}{lrrrrr}
\hline & N & Minimum & Maximum & \multicolumn{1}{c}{ Mean } & Std. Deviation \\
\hline LGY & 42 & 1.38 & 3.43 & 2.2691 & .47726 \\
ROA & 42 & 1.29 & 29.43 & 11.9486 & 7.35918 \\
DER & 42 & .20 & 4.07 & 1.1221 & .75044 \\
LGEPS & 42 & .40 & 3.98 & 1.9739 & .85308 \\
Valid N (listwise) & 42 & & & & \\
\hline
\end{tabular}

Berdasarkan tabel statistik Deskriptif menunjukkan bahwa rata-rata (mean) Nilai
Perusahaan dari perusahaan sampel selama periode pengamatan 2009-2011 sebesar 
2.2691 kali dengan standard deviasi sebesar 0.47726 , nilai standar deviasi ini lebih kecil dari pada rata-rata Nilai Perusahaan. Demikian pula nilai minimun lebih kecil dari rata-ratanya (1.38) dan nilai maksimum lebih besar dari rata-ratanya (3.43). Return On Assets yang dimiliki perusahaan food and beverages yang menjadi sampel mempunyai rata-rata sebesar 11.9486 kali dengan standard deviasi 7.35918. Return On Assets minimum 1.29 kali dan maksimum sebesar 29.43 kali.

\section{Uji Normalitas}

Histogram

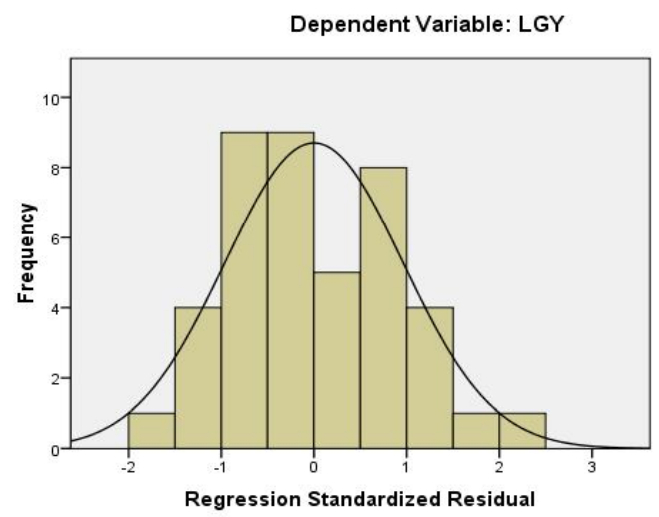

Grafik histogram menunjukkan bahwa residual terdistribusi secara normal dan membentuk simetris tidak menceng ke kanan atau ke kiri. Pada grafik normal probability
Perusahaan food and beverages yang menjadi sampel mempunyai rasio rata-rata Debt to Equity Ratio sebesar 1.1221 kali dengan standard deviasi 0.75044. Debt to Equity Ratio minimum sebesar 0.20 kali dan maksimum sebesar 4.07 kali. Sedangkan Earning Per Share memiliki rata-rata sebesar 1.9739 kali dengan standard deviasi sebesar 0.85308. Earning Per Share minimum sebesar 0.40 kali dan maksimum sebesar 3.98 kali.

Tabel 5

One-Sample Kolmogorov-Smirnov Test

\begin{tabular}{|c|c|c|c|c|c|}
\hline & & LGY & ROA & DER & LGEPS \\
\hline $\mathrm{N}$ & & 42 & 42 & 42 & 42 \\
\hline \multirow[t]{2}{*}{ Normal Parameters ${ }^{a}$} & Mean & 2.2691 & 11.9486 & 1.1221 & 1.9739 \\
\hline & Std. Deviation & .47726 & 7.35918 & .75044 & .85308 \\
\hline \multirow[t]{3}{*}{ Most Extreme Differences } & Absolute & .117 & .146 & .160 & .095 \\
\hline & Positive & .117 & .146 & .160 & .095 \\
\hline & Negative & -.057 & -.091 & -.110 & -.059 \\
\hline Kolmogorov-Smirnov Z & & .756 & .948 & 1.035 & .615 \\
\hline Asymp. Sig. (2-tailed) & & .617 & .330 & .234 & .844 \\
\hline
\end{tabular}

a. Test distribution is Normal.

plots titik-titik menyebar berhimpit disekitar diagonal dan hal ini menunjukkan bahwa residual terdistribusi secara normal.

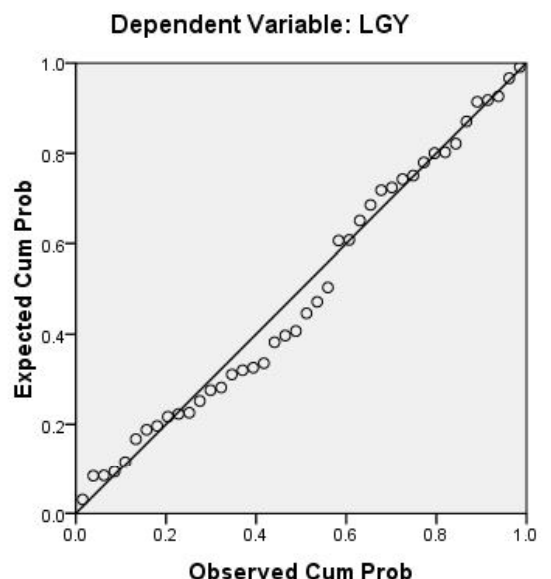


JURNAL AKUNTANSI. VOL.2 NO.1 JUNI 2014

Tabel 5

One-Sample Kolmogorov-Smirnov Test

\begin{tabular}{llrrrr}
\hline & & LGY & ROA & DER & \multicolumn{2}{c}{ LGEPS } \\
\hline $\mathrm{N}$ & & 42 & 42 & 42 & 42 \\
Normal Parameters $^{\mathrm{a}}$ & Mean & 2.2691 & 11.9486 & 1.1221 & 1.9739 \\
& Std. Deviation & .47726 & 7.35918 & .75044 & .85308 \\
Most Extreme Differences & Absolute & .117 & .146 & .160 & .095 \\
& Positive & .117 & .146 & .160 & .095 \\
& Negative & -.057 & -.091 & -.110 & -.059 \\
Kolmogorov-Smirnov Z & & .756 & .948 & 1.035 & .615 \\
Asymp. Sig. (2-tailed) & & .617 & .330 & .234 & .844 \\
\hline
\end{tabular}

Berdasarkan tabel diatas dapat dilihat bahwa nilai Kolmogorov-Smirnov untuk variabel return on assets sebesar 0.948 dengan probabilitas signifikansi 0.330 ; nilai K-S untuk variabel debt to equity ratio sebesar 1.035 dengan probabilitas signifikansi 0.234 ; nilai $\mathrm{K}-\mathrm{S}$ untuk variabel earning per share sebesar 0.615 dengan probabilitas signifikansi 0.844 ; nilai $\mathrm{K}-\mathrm{S}$ untuk variabel nilai perusahaan sebesar 0.756 dengan probabilitas signifikansi 0.617 . Berdasarkan hasil di atas, angka-angka probabilitas untuk variabel return on assets, debt to equity ratio, earning per share, dan nilai perusahaan berada diatas 0.05 , maka dapat ditarik kesimpulan bahwa data-data variabel dalam penelitian ini berdistribusi secara normal dan memenuhi uji normalitas data.

\section{Uji Multikolonieritas}

Tabel 6

Coefficients $^{\mathrm{a}}$

\begin{tabular}{|c|c|c|c|c|c|c|c|c|}
\hline \multirow[b]{2}{*}{ Mod } & & \multicolumn{2}{|c|}{$\begin{array}{l}\text { Unstandardized } \\
\text { Coefficients }\end{array}$} & \multirow{2}{*}{$\begin{array}{c}\text { Standardized } \\
\text { Coefficients } \\
\text { Beta } \\
\end{array}$} & \multirow[b]{2}{*}{$\mathrm{t}$} & \multirow[b]{2}{*}{ Sig. } & \multicolumn{2}{|c|}{ Collinearity Statistics } \\
\hline & & $\mathrm{B}$ & Std. Error & & & & Tolerance & VIF \\
\hline \multirow[t]{4}{*}{1} & (Constant) & 1.497 & .149 & & 10.057 & .000 & & \\
\hline & ROA & .030 & .010 & .459 & 3.032 & .004 & .421 & 2.378 \\
\hline & DER & -.009 & .063 & -.014 & -.142 & .888 & .970 & 1.031 \\
\hline & LGEPS & .216 & .085 & .386 & 2.528 & .016 & .414 & 2.414 \\
\hline
\end{tabular}

a. Dependent Variable: LGY

Berdasarkan tabel diatas menunjukkan bahwa tidak terdapat hubungan multikolinearitas pada variabel return on assets, debt to equity rasio, earning per share dan nilai perusahaan karena nilai VIF tidak lebih besar dari 10 dan nilai tolerance tidak ada yang kurang dari 0,10 . Hal ini juga ditegaskan kembali dari hasil korelasi antar variabel independen tidak ada korelasi yang cukup serius. 


\section{Uji Heteroskedastisitas}

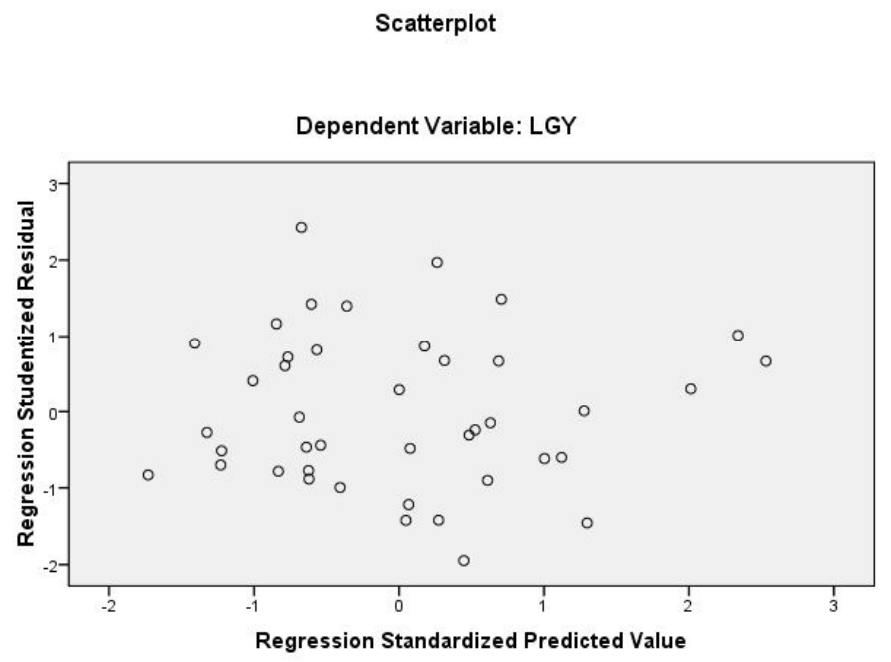

Grafik scatterplots terlihat titk-titik Hal ini dapat disimpulkan bahwa tidak menyebar secara acak (random) baik di atas terjadi heteroskedastisitas pada model maupun di bawah angka 0 pada sumbu $Y$. regresi.

\section{Uji Autokorelasi}

Tabel 7

Model Summary ${ }^{\mathbf{b}}$

\begin{tabular}{crrrrr}
\hline Model & $\mathrm{R}$ & R Square & $\begin{array}{c}\text { Adjusted } \mathrm{R} \\
\text { Square }\end{array}$ & $\begin{array}{c}\text { Std. Error of the } \\
\text { Estimate }\end{array}$ & Durbin-Watson \\
\hline 1 & $.796^{\mathrm{a}}$ & .633 & .604 & .30021 & 1.825 \\
\hline
\end{tabular}

a. Predictors: (Constant), LGEPS, DER, ROA

b. Dependent Variable: LGY

Tampilan output SPSS berikut ini menunjukkan besarnya nilai Durbin Watson sebesar 1.825. Nilai DW menurut tabel $\mathrm{dl}=1.338$ dan $\mathrm{du}=1.659$. Oleh karena nilai DW hitung > du, maka dapat disimpulkan dengan $\mathrm{n}=42$ dan $\mathrm{k}=3$ didapat angka

\section{Analisis Regresi Linear Berganda}

tidak terdapat autokorelasi antar residual.

\begin{tabular}{|c|c|c|c|c|c|c|}
\hline \multicolumn{7}{|c|}{$\begin{array}{c}\text { Tabel } 8 \\
\text { Coefficients }^{a}\end{array}$} \\
\hline & \multirow[b]{2}{*}{ Model } & \multicolumn{2}{|c|}{ Unstandardized Coefficients } & \multicolumn{2}{|l|}{$\begin{array}{l}\text { Standardized } \\
\text { Coefficients }\end{array}$} & \multirow[b]{2}{*}{ Sig. } \\
\hline & & B & Std. Error & Beta & $\mathrm{t}$ & \\
\hline \multirow[t]{4}{*}{1} & (Constant) & 1.497 & .149 & & 10.057 & .000 \\
\hline & ROA & .030 & .010 & .459 & 3.032 & .004 \\
\hline & DER & -.009 & .063 & -.014 & -.142 & .888 \\
\hline & LGEPS & .216 & .085 & .386 & 2.528 & .016 \\
\hline
\end{tabular}

a. Dependent Variable: LGY

Berdasarkan hasil analisis regresi dapat $Y=1.497+0.030$ ROA - 0.009 DER + 0.216 disusun persamaan regresi linier berganda EPS $+e$ sebagai berikut: 
Dari persamaan regresi linier berganda dapat dijelaskan :

1) Taksiran nilai perusahaan yang tidak dipengaruhi oleh return on assets, debt to equity ratio, dan earning per share adalah sebesar 1.497.

2) Nilai koefisien regresi return on assets $\left(\mathrm{X}_{1}\right)=0.030$ secara statistik menunjukkan bahwa ada pengaruh positif variabel return on assets terhadap nilai perusahaan. Nilai koefisien sebesar 0.030 memiliki arti jika nilai return on assets meningkat sebesar 1 satuan, maka nilai perusahaan meningkat sebesar 0.030 dengan asumsi variabel lain konstan.

3) Nilai koefisien regresi debt to equity ratio $\left(\mathrm{X}_{2}\right)=-0.009$ secara statistik menunjukkan bahwa ada pengaruh negatif pada variabel DER terhadap nilai perusahaan. Nilai koefisien sebesar 0.009 memiliki arti jika nilai debt to equity ratio meningkat 1 satuan, maka nilai perusahaan menurun sebesar 0.009 dengan asumsi variabel lain konstan.

4) Nilai koefisien regresi earning per share $\left(\mathrm{X}_{3}\right)=0.216$ secara statistik menunjukkan bahwa ada pengaruh positif variabel earning per share terhadap nilai perusahaan. Nilai koefisien sebesar 0.216 memiliki arti jika nilai earning per share naik sebesar 1 satuan, maka nilai perusahaan meningkat sebesar 0.216 dengan asumsi variabel lain konstan.

Uji F

\begin{tabular}{|c|c|c|c|c|c|c|}
\hline \multicolumn{7}{|c|}{$\begin{array}{l}\text { Tabel } 9 \\
\text { ANOVA }^{b}\end{array}$} \\
\hline & Model & Sum of Squares & df & Mean Square & $\mathrm{F}$ & Sig. \\
\hline \multirow[t]{3}{*}{1} & Regression & 5.914 & 3 & 1.971 & 21.872 & $.000^{\mathrm{a}}$ \\
\hline & Residual & 3.425 & 38 & .090 & & \\
\hline & Total & 9.339 & 41 & & & \\
\hline
\end{tabular}

a. Predictors: (Constant), LGEPS, DER, ROA

b. Dependent Variable: LGY

Sedikitnya ada satu variabel return on assets, yang berpengaruh signifikan terhadap nilai debt to equity ratio, dan earning per share perusahaan.

Uji t

\begin{tabular}{|c|c|c|c|c|c|c|}
\hline \multicolumn{7}{|c|}{$\begin{array}{c}\text { Tabel } 10 \\
\text { Coefficients }^{a}\end{array}$} \\
\hline & \multirow[b]{2}{*}{ Model } & \multicolumn{2}{|c|}{ Unstandardized Coefficients } & \multicolumn{2}{|l|}{$\begin{array}{l}\text { Standardized } \\
\text { Coefficients }\end{array}$} & \multirow[b]{2}{*}{ Sig. } \\
\hline & & B & Std. Error & Beta & $\mathrm{t}$ & \\
\hline \multirow[t]{4}{*}{1} & (Constant) & 1.497 & .149 & & 10.057 & .000 \\
\hline & ROA & .030 & .010 & .459 & 3.032 & .004 \\
\hline & DER & -.009 & .063 & -.014 & -.142 & .888 \\
\hline & LGEPS & .216 & .085 & .386 & 2.528 & .016 \\
\hline
\end{tabular}

a. Dependent Variable: LGY

Uji parsial digunakan untuk mengetahui pengaruh masing-masing variabel independen terhadap variabel dependen.
Sehingga masing-masing variabel bebas dapat dijelaskan sebagai berikut :

1) Berdasarkan output regresi menunjukkan bahwa return on assets 
berpengaruh positif dan signifikan terhadap nilai perusahaan. Hal ini ditunjukkan dengan $t_{\text {hitung }}$ lebih besar dari $\mathrm{t}_{\text {tabel }}(3.032>1.686)$ dengan nilai signifikansi sebesar $0.004<0.05$, maka hipotesis pertama yang menyatakan bahwa return on assets berpengaruh positif terhadap nilai perusahaan, terdukung. Dengan demikian hasil penelitian ini sependapat dengan hasil penelitian yang dilakukan Pertiwi dan Pratama (2012) menunjukkan bahwa ROA berpengaruh positif terhadap nilai perusahaan.

2) Berdasarkan output regresi menunjukkan bahwa debt to equity ratio berpengaruh negatif dan tidak signifikan terhadap nilai perusahaan. Hal ini ditunjukkan dengan $t_{\text {hitung }}$ lebih besar dari $\mathrm{t}_{\text {tabel }}(-0.142<1.686)$ dengan nilai signifikansi sebesar $0.888>0.05$, maka hipotesis kedua yang menyatakan bahwa debt to equity ratio berpengaruh positif terhadap nilai perusahaan, tidak terdukung. Dengan demikian hasil penelitian ini mendukung dari hasil penelitian Meythi (2012) yang menunjukkan bahwa struktur modal berpengaruh negatif terhadap nilai perusahaan.
3) Berdasarkan output regresi menunjukkan bahwa earning per share berpengaruh positif dan signifikan terhadap nilai perusahaan. Hal ini ditunjukkan dengan $t_{\text {hitung }}$ lebih besar dari $t_{\text {tabel }}(2.528>1.686)$ dengan nilai signifikansi sebesar $0.016>0.05$, maka hipotesis ketiga yang menyatakan bahwa earning per share berpengaruh positif terhadap nilai perusahaan, terdukung. Dengan demikian hasil penelitian ini tidak mendukung hasil penelitian Yulistiana (2010) yang menunjukkan bahwa Earning Per Share (EPS) berpengaruh negatif terhadap nilai perusahaan.

4) Berdasarkan hasil uji regresi menunjukkan bahwa secara simultan return on assets, debt to equity ratio, dan earning per share mempengaruhi nilai perusahaan. Hal ini ditunjukkan pada nilai $F_{\text {hitung sebesar } 21.872 \text { dengan }}$ signifikansi 0.000 , maka hipotesis kelima yang menyatakan bahwa variable return on assets, debt to equity ratio, dan earning per share mempunyai pengaruh yang signifikan secara simultan, terdukung.

\section{Uji $\mathbf{R}^{2}$}

Tabel 11

Model Summary ${ }^{\mathrm{b}}$

\begin{tabular}{ccrrr}
\hline Model & $\mathrm{R}$ & R Square & $\begin{array}{c}\text { Adjusted R } \\
\text { Square }\end{array}$ & $\begin{array}{c}\text { Std. Error of the } \\
\text { Estimate }\end{array}$ \\
\hline 1 & $.796^{\mathrm{a}}$ & .633 & .604 & .30021 \\
\hline
\end{tabular}

a. Predictors: (Constant), LGEPS, DER, ROA

b. Dependent Variable: LGY

Koefisien determinasi digunakan untuk menguji goodness-fit dari model regresi. Besarnya nilai Adjusted $\mathrm{R}^{2}$ sebesar 0.604 yang berarti variabilitas dependen yang dapat dijelaskan oleh variabilitas variabel independen sebesar $60 \%$. Jadi model dapat dikatakan baik karena berada diantara angka
0.60-0.799 yang berarti bahwa tingkat pengaruhnya tinggi, sedangkan sisanya $40 \%$ dijelaskan oleh variabel lainnya yang tidak dimasukkan dalam model regresi, misal tingkat suku bunga, struktur kepemilikan saham, pertumbuhan pasar, kinerja perusahaan, dan sebagainya. 


\section{KESIMPULAN}

Berdasarkan hasil penelitian dan pembahasan mengenai pengaruh Return On Assets, Debt to Equity Ratio, dan Earning Per Share terhadap nilai perusahaan, baik secara simultan maupun parsial. Hasil pengujian secara simultan menunjukkan bahwa return on assets $\left(\mathrm{X}_{1}\right)$, debt to equity ratio $\left(\mathrm{X}_{2}\right)$, dan earning per share $\left(\mathrm{X}_{3}\right)$, semua berpengaruh positif dan signifikan terhadap nilai perusahaan, sedangkan hasil pengujian secara parsial menunjukkan bahwa dari ketiga variabel independen yaitu, return on assets, debt to equity ratio, dan earning per share ada dua variabel yang berpengaruh positif dan signifikan terhadap nilai perusahaan yaitu variabel return on assets dan earning per share, sedangkan variabel debt to equity ratio tidak berpengaruh signifikan terhadap nilai perusahaan.

\section{DAFTAR PUSTAKA}

Antari, Dewa Ayu Prati Praidy dan Dana, I Made. 2013. Pengaruh Struktur Modal, Kepemilikan Manajerial, dan Kinerja Keuangan terhadap Nilai Perusahaan. Skripsi Publikasi. Universitas Udayana, Bali. 03/05/2013 16:52

Barasa, Jhojor Triwati N. 2009. Pengaruh Debt to Equity Ratio (DER), Debt to Asset Ratio (DAR) Terhadap Nilai Perusahaan pada Perusahaan Perbankan yang Terdaftar di Bursa Efek Indonesia. Skripsi Publikasi. Universitas Sumatera Utara. 29/07/2013 11:07

Juwita, Cerlienia. 2013. Pengaruh Variabel ROA, ROE, DER, EPS dan PER terhadap Return Saham Perusahaan Non Bank LQ45 Periode 2010-2012. Skripsi Publikasi. Universitas Brawijaya Malang. 29/07/2013 10:34

Kieso, Donald E, dkk. 2008. Akuntansi Intermediate. Edisi Keduabelas Jilid 1. Jakarta: Erlangga.
Meythi. 2012. Pengaruh Struktur Modal terhadap Nilai Perusahaan dengan Pertumbuhan Perusahaan sebagai Variabel Moderating. Skripsi Publikasi. Universitas Kristen Maranatha, Bandung. 16/04/2013 20:54

Pertiwi, Tri Kartika dan Pratama, Ferry Madi Ika. 2012. Pengaruh Kinerja Keuangan, Good Corporate Governance terhadap Nilai Perusahaan Food and Beverage. Jurnal Manajemen Dan Kewirausahaan, Vol.14, No. 2, September 2012: 118127. 17/07/2013 10:37

Prasetyorini, Bhekti Fitri. 2013. Pengaruh Ukuran Perusahaan, Leverage, Price Earning Ratio dan Profitabilitas terhadap Nilai Perusahaan. Jurnal Ilmu Manajemen | Volume 1 Nomor 1 Januari 2013. 16/04/2013 20:20

Priatinah, Denies dan Kusuma, Prabandaru Adhe. 2012. Pengaruh Return On Investment (ROI), Earning Per Share (EPS), dan Dividen Per Share (DPS) terhadap Harga Saham Perusahaan Pertambangan yang Terdaftar di Bursa Efek Indonesia (BEI) Periode 20082010. Jurnal Nominal / Volume I Nomor I / Tahun 2012. 29/07/2013 11:26

Puspita. 2011. Analisis Pengaruh Struktur Modal, Pertumbuhan Perusahaan, Ukuran Perusahaan, dan Profitabilitas terhadap Nilai Perusahaan pada Perusahaan Manufaktur yang Terdaftar di BEI Periode 2007-2009 Studi Kasus pada Sektor Industri Food And Beverages. Skripsi Publikasi. Universitas Diponegoro Semarang. 02/07/2012 12:50

Saputra, Anggi. 2010. Analisis Pengaruh Return On Equity (ROE), Debt Equity Ratio (DER), Price Earning Ratio (PER), Earning Growth Ratio (EGR), 
dan Return On Assets (ROA) terhadap Financial Leverage (Studi Empiris Pada Perusahaan Manufaktur di BEI). Skripsi Publikasi. Universitas Islam Negeri Syarif Hidayatullah. 29/07/2013 9:53

Sugiyono. 2007. Metode Penelitian Bisnis. Cetakan Kesepuluh. Bandung: CV. Alfabeta

Yulistiana, Ana. 2010. Pengaruh Earning Per Share (EPS), Return On Asset (ROA), Dan Arus Kas Operasi, Terhadap Nilai Perusahaan (Pada
Perusahaan Yang Terdaftar Di Jakarta Islamic Index Tahun 2004-2006). Skripsi Publikasi. UIN Sunan Kalijaga, Yogyakarta. 12/09/2013 19:36

Yuniasih, Ni Wayan dan Wirakusuma, Made Gede. 2008. Pengaruh Kinerja Keuangan terhadap Nilai Perusahaan dengan Pengungkapan Coorporate Social Responsibility dan Good Coorporate Governance sebagai Variabel Pemoderasi. Skripsi Publikasi. Universitas Udayana, Denpasar. 08/10/2012 12:50 